\title{
Society's Level of Literacy: A Cross Cultural Study
}

\author{
Amir Shoham \\ School of Business Administration, \\ The College of Management, Rishon le Zion, Israel \\ amir1s@colman.ac.il \\ Snunith Shoham \\ Department of Information Science, \\ Bar-Ilan University, Ramat-Gan, Israel \\ shohas@mail.biu.ac.il
}

\author{
Miki Malul \\ Department of Public Policy and Administration, \\ Guilford Glazer Faculty of Business and Management, \\ Ben-Gurion University of the Negev, Beer-Sheva, Israel \\ malul@som.bgu.ac.il
}

\begin{abstract}
The research suggests an additional variable to consider when answering the question, "What can explain the differences among the level of literacy in different countries?" The relationship between a country's level of literacy and its national culture is explored.

The variables from the House et al. (2004) GLOBE study were the main tools used for estimating national culture. This study focuses on the two cultural variables for which we formulated solid theoretical hypotheses, power distance (PD) and gender egalitarianism (GE).

The research results point to a positive connection between a more egalitarian society and a higher level of literacy. Societies with cultures that exhibit less discrimination between males and females have a higher level of literacy.
\end{abstract}

Keywords: Literacy, cross-cultural differences, power distance, gender egalitarianism, The GLOBES study

Material published as part of this publication, either on-line or in print, is copyrighted by the Informing Science Institute. Permission to make digital or paper copy of part or all of these works for personal or classroom use is granted without fee provided that the copies are not made or distributed for profit or commercial advantage AND that copies 1) bear this notice in full and 2) give the full citation on the first page. It is permissible to abstract these works so long as credit is given. To copy in all other cases or to republish or to post on a server or to redistribute to lists requires specific permission and payment of a fee. Contact HPublisher@InformingScience.orgH to request redistribution permission.

\section{Introduction}

According to Westby (2004), there are 875 million people in the world without access to literacy; 113 million of them are children who do not have access to school. The CIA World Factbook (2010) states that there are currently 785 million illiterate adult (age 15 and over) in the world, two third of them are women. 
There are very significant differences between the levels of literacy in different countries, as demonstrated by a series of International Adult Literacy Surveys (IALS) that were conducted in 1994, 1998, 2001 in various countries (Blum, Goldstein, \& Gue'rin-Pace, 2001; Canada, Human Resources, 2003). For purposes of the IALS survey, literacy was defined as "the ability to understand and employ printed information in daily activities, at home, at work and in the community to achieve one's goals, and to develop one's knowledge and potential" (OECD, 2000). Three types of literacy were measured: prose, document, and quantitative. Prose literacy denotes the "knowledge and skills needed to understand and use information from texts including editorials, news stories, brochures, and instruction manuals." Document literacy relates to "the knowledge and skills required to locate and use information contained in various formats, including job applications, payroll forms, transportation schedules, maps, tables and charts" and quantitative literacy refers to "the knowledge and skills required to apply arithmetic operations, either alone or sequentially, to numbers embedded in printed materials, such as balancing a check book, figuring out a tip, completing an order form, or determining the amount of interest on a loan from an advertisement."

Recognizing the importance of literacy and education, the Organization for Economic Cooperation and Development (OECD) initiated the Program for International Student Assessment (PISA) that was jointly developed by the participating countries (41-57 countries) and administered to 15-year-olds in schools. PISA assesses how well students, who are nearing the end of compulsory education, have acquired some of the knowledge and skills that are essential for full participation in society as adults. As of this writing, three assessment cycles have been conducted, in 2000, 2003 and 2006. On the basis of the test results, the participating countries were ranked and the ranking published.

The principle goal and innovation of this study is adding culture to the variables that are used to explain the difference in literacy rates among different nations.

\section{Literature Review and Hypotheses}

The level of literacy in a country or a society reflects the quality of the human capital in that country or society. "Literacy is accepted as an indispensable component of human development. Illiteracy or the absence of literacy is considered as the greatest impediment to human development" (Mazumdar, 2005, p. 98).

Low levels of literacy and general education can impede the economic development of a country in today's rapidly changing, technology-driven world. Literacy is a key factor that contributes to countries' economic growth and development, quality of life and international standing, beyond the clear advantages it has for the individual's life. Thus, Carbonaro (2006) maintains that literacy and education have significant positive associations with earning power. Hence, a UNESCO initiative aims to improve level of schooling and levels of adult literacy by 2015 (Dakar EFA goals) (UNESCO, 2006).

However, the initiative to acknowledge this fact and the decision to fight illiteracy and promote literacy can grow out of many different motivations, as the cases of China and Tanzania demonstrate. At first, the eradication of illiteracy was part of the struggle for social equality that characterized the initial transition to socialism in Tanzania and to communism in China. However, since the 1970s, both countries' government policy has focused on modernization and economic growth, which has led to changes in the motivations behind their educational policy. In China, priority was placed on those areas where the best returns on the investment were anticipated (coastal areas rather than inland, rural regions). In Tanzania, the orientation of schooling changed and it is now guided by academic excellence, certification and skills acquisition directed towards 
a human resource development model rather than social transformation aiming to create a "socialist person" (Stites \& Semali, 1991).

The differences between countries' percentages of literacy and educational levels lead to questions regarding the causes for these variations. Why do some countries attain better results? This question was raised by Le Metais and Tabberer (1997) who looked at the main reasons for international differences in student achievement. Le Metais and Tabberer compared the characteristics of 16 nations' value systems, in order to construct national profiles that reflected national contexts and priorities and then related them to each country's educational system.

Park and Kyei (2007) examine the distribution of literacy skills among adults aged 26-35 in 19 countries, focusing on the literacy gap between people whose formal educational achievement is on a high school level and those with a lower level of education. They found that the literacy gap between the poorly educated and the highly educated is relatively large in the United States, Canada, Chile and Slovenia, while it is relatively small in Germany, the Netherlands, and Denmark. The major reason for the larger gap in the former group of countries can be attributed to the substantially lower level of literacy skills among people with less education in former group of counties than in the latter. Other factors mentioned for the cross-national variation are standardization of the educational system and opportunities of post-schooling experiences, meaning the extent to which a country offers people with less educated opportunities for additional education and training, including employment experiences, adult education and training programs.

Mazumdar (2005) studied 56 countries, which were categorized as having medium and low levels of human development (according to the Index of the Human Development Report) and found that initial adult literacy and short-term growth rates of the per capita gross domestic product have significant impact on current adult literacy rate.

Other researchers have suggested several different explanations for these phenomena, mostly related to demographic variables (e.g., Parsons \& Bynner, 1998; New Zealand, Ministry of Education, 2005). Despite this, it seems that the demographic data is insufficient to provide a complete explanation for the recognizable differences between the levels of literacy in different countries. Therefore, there is a need to examine different directions and suggest additional assumptions.

In this study, the relationship between the country's level of literacy and its national culture will be explored. "Cultural differences between modern nations could be meaningfully measured and ordered along a discrete set of dimensions, representing different answers to universal problems of human societies" (Hofstede, 2006, p. 883).

According to House, Hanges, Javidan, Dorfman, \& Gupta (2004) there is no single, agreed definition for the term "culture." Social scientists generally "refer to a set of parameters of collectives that differentiate each collective in a meaningful way" (p. 15).

Sharon Glazer (2006, p. 607) states, "Cultures are comprised of people who share values, beliefs, assumptions, norms, and meanings of events or words that are learned over a period of time and often taken for granted by people living within them."

Cultural values are exogenous; in other words, they are determined outside of the model. We can expect that the marginal effect of culture on literacy will not change in the way that other independent variables explain literacy change. For example, a country's wealth can change due to a few consecutive years with high growth rates but its culture will not change for decades.

Cultural differences affect the way that people think and react. Culture is "the value shared amongst distinctive social groups and classes" (Soley \& Pandya, 2003, p. 206). House et al. (2004, p. 57) define culture as "shared motives, values, beliefs, identities, and interpretations or meanings of significant events that result from common experiences of members of collectives 
and are transmitted across age generations." Dutch anthropologist Geert Hofstede considers culture to be "the collective programming of the mind. Culture is a stem of collectively held values" (Hofstede, 1981, p. 240).

Hofstede's research on national cultural differences, published in 1980, was the first major study that converted national culture into quantitative variables. The research was conducted using questionnaires completed by 116,000 employees of IBM from 50 countries. Questions relating to the employees' values gave expression to differences between countries in four cultural dimensions: Power Distance Index (PDI), Individualism (IDV), Masculinity (MAS), and Uncertainty Avoidance (UAI). Later, a fifth dimension was added: Long Term Orientation (Hofstede \& Bond, 1988; Hofstede, 2001). Hofstede successfully linked cultural dimensions to managerial practice. Since that time, many additional studies have been conducted using cultural data to understand human behavior (e.g. Sondergaard, 1994; Sivakumar \& Nakata 1999; Dawar, Parker, \& Price, 1996; Ergeneli, Gohar, \& Temirbekova, 2007).

Furthermore, studies in other subject areas attempt to explain differences between countries by referring to their cultural characteristics. Examples include the research of Veiga, Floyd, and Dechant (2001) that deals with the disparity in ease with which IT was accepted and implemented in different countries and Van Everdingen and Waarts' (2003) study on the effect of national culture on the adoption of innovations. Furer, Liu, and Sudharshan (2000) argue that perceptions of service quality vary across cultural groups, as defined by each culture's score on Hofstede's dimensions. In the area of international marketing, there has also been a considerable amount of research that focuses on explaining the differences between countries on the basis of cultural variables (e.g. Keillor \& Hult, \& Thomas, 1999). Similarly, there are many studies of crosscultural consumer behavior (Luna \& Gupta, 2001).

Although Hofstede's cultural dimension index is still a key tool for the empirical evaluation of culture (Crotts \& Erdmann, 2000; Downey, Wentling, Wentling, \& Wadsworth, 2005; Dwyer, Mesak, \& Hsu, 2005), other researchers have augmented and refined his index of cultural characteristics. Another classification of culture was proposed by Shalom Schwartz (1994, 1999), who identified three fundamental value pairs distinguishing all cultures: autonomy versus embeddedness (conservatism); hierarchy versus egalitarianism and mastery versus harmony. His samples included students in 54 countries and elementary school teachers in 56 countries. His variables are well-known and widely used in international research in many fields.

One study that applied Schwartz's culture values is Glazer's (2006) examination of perceptions of social support. The study investigated perceptions of emotional support from superiors and instrumental support from co-workers among 15,606 employees, on various organizational levels, in a multinational company distributed in 19 countries, representing five geographic and/or social regions: English-speaking countries, Western Europe, Latin America, Eastern Europe, and Asia.

A newer scale proposed by House et al. (2004) is based on research done in 62 different societies and cultures and defines nine cultural dimensions: Uncertainty Avoidance, Power Distance, Institutional Collectivism, Gender Egalitarianism, Assertiveness, Future Orientation, Performance Orientation, and Human Orientation (see Appendixes B for short definitions of the dimensions). The cross-cultural GLOBE study (House et al., 2004) tried to explain the relationships between different leadership patterns and organization's practices and society's culture, using data gathered from 17,370 middle managers working in 951 different local organizations in 62 countries, chosen from the following industries: food processing, financial services, and telecommunication services. The indices were calculated on the basis of 371 cultural items relating to organizational culture and societal culture. The respondents were asked to rate, on a scale of 7 points, how things are ("As Is" items) and also how things should be ("Should Be" items) in the organization where they work and in their society. This reflects the GLOBE research project's examination of culture 
as practices and values. "Practices are acts or the way things are done in the culture, and values are artifacts because they are human made and ... are judgments about the way things should be done" (House et al., 2004, p. xv). Leung (2006, p. 881) called the GLOBE study, "probably the most sophisticated project undertaken in international business research."

We hold that the aforementioned impact of country's culture applies to select cultural variables that embed society's level of literacy - in other words, to those cultural dimensions that have direct bearing on literacy. We follow Shenkar's (2001) approach that claims that in using the culture variable as an independent variable, each variable should be used separately and not as an aggregate culture. This is due to the fact that not all culture variables impact a specific dependent variable. This approach is becoming more common in international business research (Brock, Shenkar, Shoham, \& Siscovick, 2008). In the following paragraphs, we identify those dimensions from among a repertoire of cultural classifications in a GLOBE study (House et al., 2004) yielding Power Distance (PD) and Gender Egalitarianism (GE) as major predictors of literacy levels.

We were able to establish a solid hypotheses relating culture to literacy for two cultural variables, power distance and gender.

Power distance (PD), is a dimension identified by both GLOBE and Hofstede, is the degree to which people expect power and authority to be distributed and expressed equitably or inequitably (Carl, Gupta, \& Javidan, 2004; Hofstede, 1980, 1983). The term was coined by Mulder (1977) who wrote about the degree of inequality in power between a less powerful individual and a more powerful individual, where both belong to the same social system. Hofstede stated, "The basic issue involved is human inequality. Inequality can occur in areas such as prestige, wealth, and power; and different societies put different weights on status constituency among these areas" (Hofstede, 2001, p. 75). Hofstede's power distance index was intended to measure the extent to which a society accepts the unequal distribution of power in institutional and organizational environments.

In cultures with a high level of power distance, some individuals are perceived as having higher overall rank and their power is unquestionable and unattainable by those with less power. In countries with a low level of power distance each individual is respected and appreciated for what that person has to offer and people expect access to upward mobility in both their class and their jobs (Carl, et al., 2004, 518). Carl, Gupta, and Javidan (2004) further claimed that level of power distance within societies can be traced to four fundamental phenomena: the predominant religion or philosophy, the tradition of democratic principles of government, the existence of a strong middle class and the proportion of immigrants in a society's population.

In the GLOBE project, Power Distance was defined as "the degree to which members of an organization or society expect and agree that power should be shared unequally" (Carl, et al., 2004, p. 517). They measured Power Distance (PD) by two scales: practices ("As Is") and values ("Should Be") at two levels of analysis: societal level and organizational level. The Globe measures of PD represent the degree to which a community maintains inequality among its members by stratification of individuals and groups with respect to power, authority, prestige, status, wealth, and material possessions.

The direction of the impact of PD on level of literacy is not clear; it can be either positive or negative. The negative relationship is derived directly from the definition of power distance. The source of a positive relationship can be attributed to the common knowledge that education is one of the best ways to mobilize an individual from a poorer social condition to a better one.

Hypothesis 1: A high level of power distance in a country's culture will be positively or negatively related to literacy. 
Gender Egalitarianism (GE) refers to the extent to which an organization or society minimizes gender role differences and gender discrimination, while promoting gender equality, in comparison to other societies that have more gender differentiation. Hofstede (1980) claimed that one of the most fundamental ways in which societies differ is in the extent to which each prescribes and proscribes different roles for women and men. Therefore, he suggested the masculinity/femininity dimension, which addressed the problem of "duality of female versus male" (Hofstede, 1998, p.11). The masculinity/femininity dimension includes two aspects: 1. differences among societies regarding the extent to which each emphasizes and rewards masculine values such as assertiveness, success and competition versus feminine values such as solidarity and caring; 2 . differences among societies regarding their beliefs about the behavior that is appropriate for males versus females. In more masculine cultures, males are expected to be assertive and tough while females are expected to be modest and tender. In more feminine culture, both males and females are expected to be modest and tender.

In the GLOBE project, gender egalitarianism is defined as "the beliefs about whether members' biological sex should determine the role they play in their homes, business organizations, and communities" (Emrich, Denmark, \& Den Hartog, 2004, p. 347). They assumed that societies with greater gender egalitarianism rely less on biological sex to determine the allocation of roles between the sexes. The GLOBE project conceptualized and measured two components of gender egalitarianism: 1 . the attitudinal domain, which relates to fundamental values, beliefs, and attitudes held by members of a society regarding gender stereotypes and gender-role ideology; 2 . behavioral manifestations, mainly actions and behaviors related to gender egalitarianism that are observed in a society; for example, gender discrimination and gender equality.

The GLOBE project measured gender egalitarianism on the societal level by asking the participating managers to complete two scales: one that assessed their perceptions of the current degree of gender egalitarianism in their society (practices, "As Is") and another that assessed their perceptions of the ideal degree of gender egalitarianism in their society (values, "Should Be"). The same method was used for organizational gender egalitarianism.

Hypothesis 2: High levels of Gender Egalitarianism in a country's culture will be positively related to literacy.

\section{Methodology}

As noted above, the main goal of the current research is to present and test cultural dimensions as a variable that can add to the explanation of literacy differences among countries.

We were able to establish a solid hypotheses relating culture to literacy for two cultural dimensions, Power Distance and Gender Egalitarianism. Our empirical research tests the two hypotheses we developed and presented in the previous section.

\section{Sample}

The sample used in this study includes 56 of the countries that House, et al. (2004) included in the GLOBE study of culture variables, omitting countries with multiple scores, like South Africa where the black and white populations were scored separately. The list of countries may be found in Annex A. The sample is very diverse; it contains countries from all continents and of all types of wealth.

\section{The Variables}

The source of data for the control variables and dependent variable (literacy) is CIA World Fact Book 2007. 


\section{Dependent variable}

Literacy. The literacy rate for each country was measured on the basis of Census Bureau percentages for the total population, for males and for females. All rates are based on the most common definition of literacy, the ability to read and write at a specified age (as defined by World Factbook, 2007).

\section{Independent variables}

This study uses two types of independent variables (a) cultural variables and (b) control variables, which are economic and demographic variables.

Cultural variables. National culture was primarily estimated using variables ("as is") from the House, et al. (2004) GLOBE study of 62 societies. The two cultural variables used in this research were those for which we formulated a solid theoretical hypotheses, power distance (PD) and gender egalitarianism (GE). These variables were described in the previous section.

Control variables. Five control variables were used: population, gross domestic product per capita, the Gini index, budget/population and globalization.

1. Population or the number of inhabitants in each country. Population figures are based on estimates made by the United States Census Bureau, based on statistics from population censuses, vital statistics registration systems or sample surveys pertaining to the recent past and assumptions about future trends. When controlling for the other variables, we expect to find a negative correlation between the level of literacy and the size of the population (Rose, 2006).

2. Gross Domestic Product Per Capita (GDPPC) is the country's Gross Domestic Product (GDP) divided by population as of 1 July 2006 and expressed on the basis of purchasing power parity (PPP). We expect that the wealthier the economy, the higher the level of literacy will be because more resources are available for providing literacy to more people. Our expectation is consistent with Verner (2005) who found that from a certain threshold of income the correlation between GDP Per capita and the level of literacy rate is positive.

3. The Gini Index (Distribution of family income): In this paper, economic inequality is measured using the Gini Index, which assesses the extent to which the distribution of income among households within a country deviates from a perfectly equal distribution. If income were distributed with perfect equality, the index would be zero; if income were distributed with perfect inequality, the index would be 1 . We expect that the relationship between the level of literacy and the Gini index will be negative, meaning that a higher level of inequality in the population will lead to lower share of literacy. As more resources go to a smaller part of the population, the less likely there are to be enough resources remaining to create and distribute literacy among the rest of the population. Our expectation is consistent with Ahluwalia (1976) who found a positive correlation between literacy and the share of the income held by lowest $40 \%$ population.

4. Budget/Population: ratio between the government budget and the country's population. The budget includes both expenditures and capital expenditures. These figures were calculated on an exchange rate basis rather than in terms of purchasing power parity. Verner (2005) found week (not significant) positive relation between public expenditure on education and literacy rate. We expect that the relationship between the budget per population and the level of literacy would be positive since we assume that the government will use its budget in order to provide services for the entire population, especially basic education. 
5. The Globalization variable reflects the scope of interactions between the country and the world. An acceptable measure for this is the ratio between the sum of import and export in relation to the GDP, $\frac{\operatorname{IMPORT}(\$)+E X P O R T(\$)}{G D P(\$)}$.

We expect that when the globalization level increases, meaning when the local economy is more globalized, it requires more specialization of its economic units and it becomes necessary to increase the educational level of people who already have a certain level of education. This process might leave fewer resources for basic education for the relatively weak populations, especially the population living in peripheral areas. Therefore, there could be an increase in the average level of education but lower levels of literacy. This expectation is consistent with the findings of Baliamoune-Lutz (2006) who found a negative correlation between the level of literacy and the degree of openness to the world economy.

\section{Analysis}

We conducted a Kolmogorov-Smirnov Goodness-of-Fit test on the dependent variable. The results showed that the P-Value of the test was 0.008 meaning that the dependent variable, literacy, lacks a normal distribution. Since our sample was small, it is probable that the distribution of errors is abnormal. To bypass this problem we converted the dependent variable (literacy) into a binary variable with 1 representing countries with a higher than the average percentage of literacy and 0 representing countries with a lower than the average percentage of literacy. Table 1 displays the results of the Logit regression. Since the sample includes only 56 observations, the degrees of freedom (FD) allowed us to use a maximum of seven independent variables.

Table 1: Logit Regression For Literacy

\begin{tabular}{lrrr|}
\hline Variable & Regression 1 & \multicolumn{2}{|c|}{ Regression 2 } \\
\hline C & -78 & -45 \\
Population & $-0.073^{+}$ & $-0.019^{+}$ \\
GDPPC & $0.002^{*}$ & $0.001^{* *}$ \\
Gini & $-0.528^{*}$ & $-0.076^{+}$ \\
Budget/Population & $-2.88^{*}$ & $-0.7^{*}$ \\
GLOB & $-10.7^{*}$ & $-2.43^{*}$ \\
GE & $17.8^{*}$ & \\
PD & 7.9 & 4.5 \\
Cox \& Snell R ${ }^{2}$ Nagelkerke $\mathrm{R}^{2}$ & 0.654 & 0.55 \\
& 0.902 & 0.759 \\
The change in Cox \& Snell $\mathrm{R}^{2}$ & & 0.104 \\
attributed to GE & & 0.143 \\
The change in Nagelkerke $\mathrm{R}^{2}$ & & \\
attributed to GE & & \\
$* *$ P-Value $<0.01$ P-Value $<0.05+\mathrm{P}-$ Value $<0.1$ & &
\end{tabular}


Table 1 displays the connections found between the level of literacy and the cultural variables and control variables. Since there is no Adjusted R Square for the logit regression, we used two alternatives, the Cox \& Snell R Square and the Nagelkerke R Square. As the table shows, both produce high results, meaning that the degree to which the independent variables explain the literacy regression is high.

The cultural variables used in the regression were Gender Egalitarianism (GE) and Power Distance (PD); the first was found to be significant but not the latter, This means that hypothesis 1 was not supported while hypothesis 2 was supported. The less separation there is between men and women in a nation's social culture, the larger the proportion number of people in the country who know how to read and write. Although PD was not found to be significant, it is worthwhile noting that it has a positive influence on the likelihood that people in the country are literate.

To strengthen this conclusion and further support hypothesis 2, we use Darlington's (1968) technique for isolating the impact of each undefended variable by running regressions with and without a specific undefended variable. A difference in the R-squares is attributed to the unique contribution of the isolated variable. Shaw, Gupta, and Delery (2000) used Darlington's technique to confirm their hypotheses even when the difference in the R-squares were 0.013 . As can be seen in Table 1 regression 2, the GE variable attributed to the Cox \& Snell $R^{2} 0.104$ and 0.143 to the Nagelkerke $\mathrm{R}^{2}$. In both the R-Squares far exceed 0.013 . All these results indicate that a country with high GE tend to have higher literacy rates than a country with lower GE.

Regarding the control variable, analysis of the data presented in Table 1 shows that when the size of the population increases, the likelihood of a high literacy rate drops significantly. This means that a country like China or India can be expected to have a lower literacy rate than countries with smaller populations. A significant, positive connection was found between the GDPPC and literacy. Wealthier countries, with a higher per capita product, tend towards a higher literacy rate. This can be explained by the fact that wealthy countries are able to allocate more resources, both private and public, to education.

Countries with a less equal distribution of income, as measured by the Gini Index, were found to have a significantly smaller number of literate people. Similarly, where the national budget/population is higher, the level of literacy was found to be significantly lower. This is a very surprising result that is contrary to our expectation for a positive sign. This result could be used to support claims for a free-market policy with a low level of government intervention since it shows that a high level of government spending leads to a lower level of literacy.

The globalization (GLOB) finding is particularly interesting. The higher a country's GLOB score, the more likely it is to have a lower number of people who know how to read and write. Apparently, this result is reasonable when considering that manner in which the GLOB index is calculated (see the section on the control variables, above). Particularly impoverished countries tend to import many products, including investment goods that they are unable to produce. Therefore, countries with a low GDP combined with a comparatively high level of imports have a high GLOB score. For example, Guatemala received a high score on the globalization index, as did Georgia, Zimbabwe and Zambia while the United States, which produces many products and services for its own domestic market, scored low.

The logit regression is a binary regression. A positive coefficient indicates a higher probability of having variable 1 (literacy) and a negative coefficient means a lower probability of literacy. Equation 1 shows how the coefficients indicate the probability of having literacy: 
$P_{i}=\frac{e^{x b}}{e^{x b}+1}=\frac{1}{1+e^{-x b}}$

$\mathrm{P}=$ the probability of having variable 1 (literacy).

$\mathrm{X}=$ the vector of the variables of the logit regression

$b=$ the vector of the coefficients of the variables in the logit regression.

We used the above equation to find the marginal impact that GE (Gender Egalitarianism) has on the probability of having variable 1 (literacy). We use GE as an example, but the same relationships would be seen using the other variables. Equation 2 contains GE results of the logit regression. Note that the coefficient 17.8 is taken from the logit results (Table 1) for GE.

$$
P=\frac{1}{1+e^{-17 \cdot 2 * G E-x b}}
$$

The results of Equation 2 are displayed in Figure 1. The $\mathrm{Y}$ axis shows the marginal effect on literacy probability (from 0 to 1 ); and the $\mathrm{X}$ axis, the GE for the values 2.5 to 4.08 . The lowest score for GE was 2.5 for South Korea and the highest was 4.08 for Hungary. The average score for GE in the sample was 3.38 .

Figure 1 shows that if GE is 3.1 or lower, the marginal change in the probability of having a higher percentage of literacy is almost 0 . If the GE of a country is higher than 3.1, the marginal effect on the probability that a country will have a higher than the average percentage of literacy starts to rise dramatically. At GE 3.6 and above, the marginal effect on probability approached its maximum level.

\section{Figure 1: GE effect on probability of literacy}

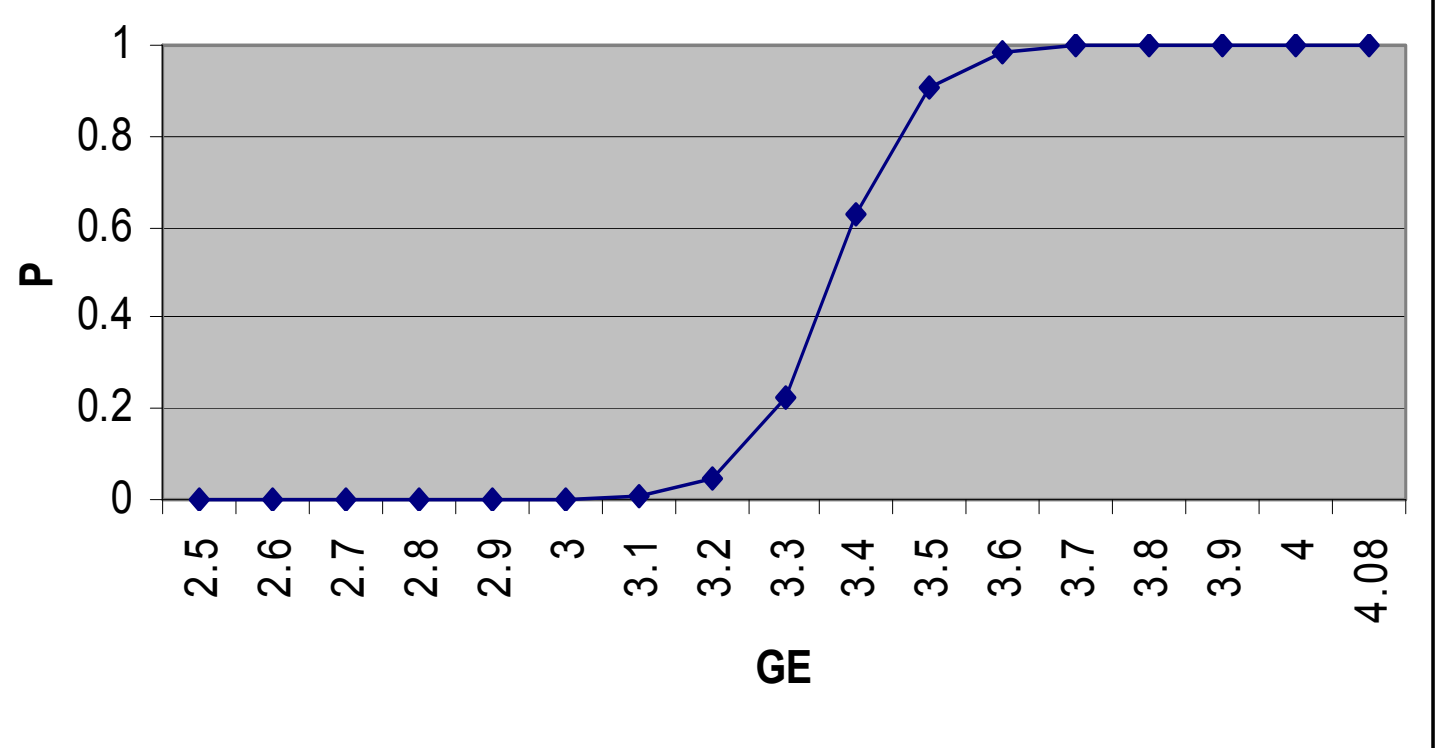




\section{Discussion and Conclusions}

This study examined the level of literacy in 56 different countries on all continents. Literacy levels were examined in light of the economic and social characteristics of the countries included in the sample. The main contribution of the research is the addition of culture to the variables influencing literacy rates of different nations. From the nine culture dimensions GLOBE study (House et al, 2004) has scores we developed hypothesis for two cultural variables. Out of the two, just GE was significant leading to the conclusion that the more egalitarian a society is, the higher its literacy level. This is evident in the following findings: societies or cultures that show less discrimination against women and have a higher level of Gender Egalitarianism also have a higher level of literacy. Examining equation 2 and Figure 1 gives us an idea of the impact of GE on the probability of a nation moving from below average literacy to above the average literacy. For example, the marginal effect on the probability with a score of 3 (variable scores between 0 and 7 ) is almost zero, and a score of 3.38 has a marginal effect on the probability of 50 present being over the average literacy.

Similarly, countries with a lower Power Distance are more likely to have a higher level of literacy (although this coefficient was not found to be statistically significant).

The control variables also have significant impact on literacy, as expected. The Gini index, which measures the distribution of income in a country, reinforces the assertion that there is a connection between a society's equality level and its literacy rate. It was also found that wealthier countries have a higher literacy rate while the other economic and social variables point to the conclusion that large population, unequal income distribution, a high national budget per population and a high globalization index contribute to an increased likelihood of a low literacy rate.

The findings regarding culture (GE and PD), unequal distribution of income and population size can be understood. The findings regarding large budget/population and a high globalization score raise questions. A large national budget per person is indicative of centralization, government involvement in the economy and a limited free market. It would appear that systems, especially educational systems are more effective when there is room for independent initiatives. Regarding globalization, a high score is characteristic of poor nations that must import finished products while exporting mostly raw materials.

This study is innovative in that it relates not only to quantitative economic indices but also to cultural indices. It points to a positive connection between a more egalitarian society with free markets and a higher level of literacy.

\section{References}

Ahluwalia, M. S. (1976). Inequality, poverty and development. Washington., DC: World Bank.

Blum, A., Goldstein, H., \& Gue'rin-Pace, F. (2001). International adult literacy survey (IALS): An analysis of international comparisons of adult literacy. Assessment in Education, 8(2), 225-246.

Baliamoune-Lutz, M. (2006). Globalization and gender inequality: Is Africa different? Journal of African Economies, 16(2), 301-348.

Brock, D. M., Shenkar, O., Shoham, A., \& Siscovick, I. C. (2008). National culture and expatriate deployment. Journal of International Business Studies, 39(8), 1293-1309.

Canada, Human Resources and Social Development. (2003). Literacy in the information age - Highlights from the final report of the International Adult Literacy Survey. Retrieved October 14, 2007 from http://www.hrsdc.gc.ca/en/hip/lld/nls/Surveys/ialsfrh.shtml

Carbonaro, W. (2006). Cross-national differences in the skills-earnings relationship: The role of labor market institutions. Social Forces, 84(3), 1819-1842. 
Carl, D., Gupta, V., \& Javidan, M. (2004). Power distance. In R. J. House, P. J. Hanges, M. Javidan, P. W. Dorfman, \& V. Gupta (Eds.), Culture, leadership, and organizations: The GLOBES study of 62 societies. Thousand Oaks, CA: Sage Publications. (pp. 513-563).

CIA World Factbook. (2007). Retrieved October 18, 2007 from http://www.cia.gov/cia/publications/factbook/index.html

CIA World Factbook: Literacy (2010). Retrieved Februaty 18, 2011 from https://www.cia.gov/library/publications/the-world-factbook/fields/2103.html

Crotts, J. C., \& Erdman, R. (2000). Does national culture influence consumer evaluation of travel services? A test of Hofstede's model of cross-cultural differences. Managing Service Quality, 10 (6), 410-419.

Darlington, R. B. (1968). Multiple regressions in psychological research and practice. Psychological Bulletin, 69, 161-182.

Dawar, N., Parker, P. M., \& Price, L. J. (1996). A cross-cultural study of international information exchange. Journal of International Business Studies, 27 (3), 497-516.

De Luque, M. S., \& Javidan, M. (2004). Uncertainty avoidance. In R. J. House, P. J. Hanges, M. Javidan, P. W. Dorfman, \& V. Gupta (Eds.), Culture, leadership, and organizations: The GLOBES study of 62 societies (pp. 602-653). Thousand Oaks, CA: Sage Publications.

Den Hartog, D. N. (2004). Assertiveness. In R. J. House, P. J. Hanges, M. Javidan, P. W. Dorfman, \& V. Gupta (Eds.), Culture, leadership, and organizations: The GLOBES study of 62 societies (pp. 395436). Thousand Oaks, CA: Sage Publications.

Downey, S., Wentling, R. M., Wentling, T., \& Wadsworth, A. (2005). The relationship between national culture and the usability of an e-learning system. Human Resource Development International, 8(1), $47-64$.

Dwyer, S., Mesak, H., \& Hsu, M. (2005). An exploratory examination of the influence of national culture on cross-national product diffusion. Journal of International Marketing, 13(2), 1-27.

Emrich, C. G., Denmark, F. L., \& Den Hartog, D. N. (2004). Cross-cultural differences in gender egalitarianism: Implications for societies, organizations, and leaders. In R. J. House, P. J. Hanges, M. Javidan, P. W. Dorfman, \& V. Gupta (Eds.), Culture, leadership, and organizations: The GLOBES study of 62 societies (pp. 343-394). Thousand Oaks, CA: Sage Publications.

Ergeneli, A., Gohar, R., \& Temirbekova, Z. (2007). Transformational leadership: Its relationship to culture value dimensions. International Journal of Intercultural Relations, 31, 703-724.

Furer, O., Liu, B. S-C., \& Sudharshan, D. (2000). The relationships between culture and service quality perceptions: Basis for cross-cultural market segmentation and resource allocation. Journal of Service Research, 2(4), 335-371.

Glazer, S. (2006). Social support across cultures. International Journal on Intercultural Relations, 30, 605622.

Hofstede, G. (1980). Culture's consequences: International differences in work-related values. Beverly Hills, CA: Sage Publications.

Hofstede, G. (1981). Cultures and organizations. International studies of management and organization, $X$ (4), 15-41.

Hofstede, G. (1983). The cultural relativity of organizational practices and theories. Journal of International Business Studies, 14 (Fall), 75-89.

Hofstede, G. (1998). Masculinity and femininity: The taboo dimension of national cultures. Thousand Oaks, CA: Sage.

Hofstede, G. (2001). Culture's consequences: International differences in work-related values. London: Sage. 
Hofstede, G. (2006). What did GLOBE really measure? Researchers' minds versus respondents' minds. Journal of International Business Studies, 37, 882-896.

Hofstede, G., \& Bond, M. H. (1984). Hofstede's culture dimensions: An independent validation using Rokeach's value survey. Journal of Cross-Cultural Psychology, 15(December), 417-433.

Hofstede, G., \& Bond, M. H. (1988). Confucius and economic growth: New trends in culture's consequences. Organizational Dynamics, 16(4), 4-21.

House, R. J., Hanges, P. J., Javidan, M., Dorfman, P. W., \& Gupta, V., Eds. (2004). Culture, leadership, and organizations: The GLOBE study of 62 societies. Thousand Oaks, CA: Sage Publications.

Keillor, B. D., Hult, G., \& Thomas M. (1999). A five-country study of national identity implications for international marketing research and practice. International Marketing Review, 16(1), 65-84.

Le Metais, J., \& Tabberer, R. (1997). Why different countries do better: Evidence from examining curriculum and assessment frameworks in 16 countries. International Electronic Journal for Leadership in Learning, 1 (May). Available at www.ucalgary.ca/ iejll

Leung, K. (2006). Editor's introduction to the exchange between Hofstede and GLOBE. Journal of International Business Studies, 37(November), 881.

Luna, D., \& Gupta, S. F. (2001). An integrative framework for cross-cultural consumer behavior. International Marketing Review, 18(1), 45-69.

Mazumdar, K. (2005). Socio-economic factors determining adult literacy in developing countries. International Journal of Social Economics, 32(1/2), 98-120.

Mulder, M. (1977). The daily power game. Leydem, The Netherlands: Martinus Nijhoff.

New Zealand, Ministry of Education. (2005). Analysis of New Zealand data from the International Adult Literacy Survey: Demographic predictors of low literacy proficiency: Final report. Retrieved February 18,2007 from http://literacy.massey.ac.nz/fileadmin/files/Files/Analysis\%20of\%20New\%20Zealand\%20Data.pdf

OECD. (2000). Literacy in the information age: Final report of the International Adult Literacy Survey. Canada: Statistics Canada.

OECD Program for International Student Assessment (PISA). (2006). Retrieved February 20, 2008 from http://pisaweb.acer.edu.au/oecd/oecd_pisa_data.html

Park, H., \& Kyei, P. (2007). Literacy gaps by educational attainment: A comparative study of 19 countries. Working Paper Series 07-12. Population Aging Research Center, University of Pennsylvania. Retrieved March 12, 2009 from http://repository.upenn.edu/cgi/viewcontent.cgi?article=1000\&context=parc_working_papers

Parsons, S., \& Bynner, J. (1998). Influences on adult basic skills: Factors affecting the development of literacy and numeracy from birth to 37. United Kingdom: Basic Skills Agency.

Rose, A. K. (2006). Size really doesn't matter: In search of a national scale effect. Journal of the Japanese and International Economies, 20(4), 482-507.

Schwartz, S. H. (1994). Beyond individualism/collectivism: New cultural dimensions of values. In U. Kim, H. C. Triandis, C. Kagitcibasi, S-C. Choi, \& G. Yoon (Eds.), Individualism and collectivism: Theory, method and applications (pp. 85-99). California: Sage Publications.

Schwartz, S. H. (1999). A theory of cultural values and some implications for work. Applied Psychology: An International Review, 48, 23-47.

Shaw, J. D., Gupta, N., \& Delery, J. E. (2000). Empirical organizational-level examinations of agency and collaborative predictions of performance-contingent compensation. Strategic Management Journal, 21, 611-623.

Shenkar, O. (2001). Cultural distance revisited: Towards a more rigorous conceptualization and measurement of cultural differences. Journal of International Business Studies, 32(3), 519-535. 
Sivakumar, K., \& Nakata, C. (1999). The stampede toward Hofsted's framework: Avoiding the sample design Pit in cross-cultural business studies. AMA Summer Educators' Conference, San Francisco.

Sondergaard, M. (1994). Hofstede's consequences: A study of reviews, citations and replications. Organization Studies, 15(3), 447-456.

Soley, M., \& Pandya, K. V. (2003). Culture as an issue in knowledge sharing: A means of competitive advantage. Electronic Journal of Knowledge Management, 1(2), 205-212. Retrieved April 10, 2004 from http://www.ejkm.com/volume-1/volume1-issue-2/issue2-art20-soley.pdf

Stites, R., \& Semali, L. (1991). Adult literacy for social equality for economic growth? Changing agendas for mass literacy in China and Tanzania. Comparative Education Review, 35(Feb), 44-75.

UNESCO. (2006). Education for all: Literacy for life. (EFA Global Monitoring Report 2006). Paris: UNESCO.

Van Everdingen, Y. M., \& Waarts, E. (2003). The effect of national culture on the adoption of innovations. Marketing Letters, 14(3), 217-232.

Veiga, J. F., Floyd, S., \& Dechant, K. (2001). Toward modeling the effects of national culture and IT implementation and acceptance. Journal of Information Technology, 16, 145-158.

Verner, D. (2005). What factors influence world literacy? Is Africa different?' World Bank Policy Research Working Paper no. 3496.

Westby, C. (2004). $21^{\text {st }}$ Century literacy for a diverse world. Folia Phoniatrica et Logopaedica, 56, 254271. 


\section{Appendix A: List of Countries}

Albania

Argentina

Australia

Austria

Bolivia

Brazil

Canada

China

Colombia

Costa Rica

Denmark

Ecuador

Egypt

El Salvador

England

Finland

France

Georgia

Greece

Guatemala

Hong Kong

Hungary

India

Indonesia

Iran

Ireland

Israel

Italy
Japan

Kazakhstan

Kuwait

Malaysia

Mexico

Morocco

Namibia

Netherlands

New Zealand

Nigeria

Philippines

Poland

Portugal

Qatar

Russia

Singapore

Slovenia

South Korea

Spain

Sweden

Switzerland

Taiwan

Thailand

Turkey

United States

Venezuela

Zambia

Zimbabwe 


\section{Appendix B: Definitions of GLOBE Cultural Dimensions}

\begin{tabular}{|c|c|}
\hline Cultural dimension & Definition \\
\hline Assertiveness & $\begin{array}{l}\text { "The degree to which individuals .... are assertive, tough, dominant, } \\
\text { and aggressive" (Den Hartog, 2004, p. 395). }\end{array}$ \\
\hline Future orientation & $\begin{array}{l}\text { "The degree to which individuals ... engage in future-oriented be- } \\
\text { haviors such as planning, investing... and delaying ... gratification" } \\
\text { (House \& Javidan } 2004, \text { p. 12). }\end{array}$ \\
\hline Gender egalitarianism & $\begin{array}{l}\text { "The degree to which an organization or a society minimizes gender } \\
\text { role differences while promoting gender equality" (House \& Javi- } \\
\text { dan, 2004, p.12). }\end{array}$ \\
\hline Humane orientation & $\begin{array}{l}\text { "The degree to which individuals in organizations or societies en- } \\
\text { courage and reward individuals for being fair, altruistic, friendly,... } \\
\text { and kind" (House \& Javidan, 2004, p. 13). }\end{array}$ \\
\hline In-group collectivism & $\begin{array}{l}\text { "The degree to which individuals express pride, loyalty and cohe- } \\
\text { siveness in their organizations or families" (House \& Javidan, 2004, } \\
\text { p. 12). }\end{array}$ \\
\hline Institutional collectivism & $\begin{array}{l}\text { "The degree to which organizational and societal institutional prac- } \\
\text { tices encourage and reward collective distribution of resources and } \\
\text { collective action" (House \& Javidan 2004, p. 12). }\end{array}$ \\
\hline Performance orientation & $\begin{array}{l}\text { "Reflects the extend to which a community encourages and rewards } \\
\text { innovation, high standards, and performance improvement" (Javi- } \\
\text { dan, 2004, p. 239). }\end{array}$ \\
\hline Power distance & $\begin{array}{l}\text { "The extend to which a community accepts and endorses authority, } \\
\text { power differences, and status privileges" (Carl, et al., 2004, p. 513). }\end{array}$ \\
\hline Uncertainty avoidance & $\begin{array}{l}\text { "The extent to which ambiguous situations are threatening to indi- } \\
\text { viduals, to which rules are preferred, and to which uncertainty is tol- } \\
\text { erated" (de Luque \& Javidan, p. 2004, 602). }\end{array}$ \\
\hline
\end{tabular}




\section{Biographies}
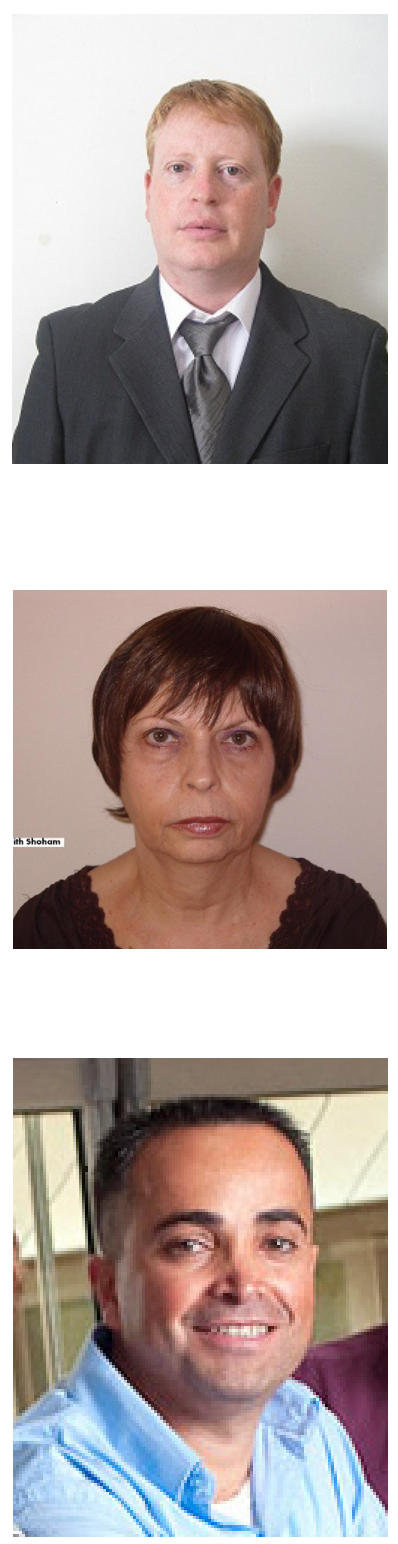

Amir Shoham (PhD) holds degrees in Economics and Business Administration from Ben-Gurion University, Israel. He is currently on the faculty of the Finance department, School of Business Administration, College of Management - Academic Studies in Israel. Dr. Shoham also teaches in academic institutions in other countries including USA, China, France, and Singapore. The courses he teaches include Managerial Economics, Introduction to Finance, International Finance and International Financial Strategies. Recently, he has published articles in Journal of International Business Studies, The Global Economy Journal, and Journal of Socio-Economics. Born in Israel, he is an Israeli citizen.

Snunith Shoham $(\mathrm{PhD})$ has a doctorate degree from the University of California, Berkeley, School of Library and Information Studies. She was the Chair of the Department of Information Science, Bar Ilan University, Israel (1998-2005). She has published the books Organizational Adaptation by Public Libraries (Greenwood Press, 1984) and Classification and Browsing: The Conjunction of Readers and Documents (Sussex Academic Press, 2000) as well as many articles on information gathering behavior, knowledge organization, and public libraries.

Miki Malul (PhD) is a faculty member in the Guilford Glazer School of Business and Management, Ben-Gurion University of the Negev and in the Department of Public Policy and Administration in Israel. $\mathrm{He}$ is a member of the economics team of The Taub Centre for Social Policy Studies in Israel. Dr. Malul's current research interests are regional economics, labor economics policies, and peace economics. He has experience teaching economics, public policy and finance in various MBA and BA programs. Recently, he has published articles in $U r$ ban Studies, The B.E journal of Economic Analysis and Policy and Review of Social Economics. 